\title{
The Role of Non-Governmental Organizations (NGOs) in Post-Conflict Peace Building in North Eastern, Nigeria
}

\section{Ghani Dass Mohammed* and Abdullahi Yalwa}

School of General Studies, Abubakar Tatari Ali Polytechnic, Bauchi, Nigeria

\begin{abstract}
Nigeria as a sovereign state is characterized by the dynamics of crisis which slow-pace of its developments in all ramifications. The ill political will on the part of the government to address the post-conflict phenomena, particularly in north-eastern part of Nigeria, became an issue which draw the attention of the local and international community. This development specially dragged the attention of the non-governmental organizations (NGOs) in handling humanitarian services at various internally displaced camps, of the region. Elite theory which hinges on the thrust that public policy is by and large the mirror image of elite interest was employed to guide the analysis of this work. Content analysis was equally used as a source of data collection and it revealed that the Non-governmental Organizations (NGOs) are institution of humanitarian services characterized with some pitfalls, in the post-conflict areas of the north-eastern Nigeria. The paper critically reviewed the existing literature both conceptually and thematically and relied on secondary source of data and examination of official documents as its methodology. The paper is structured into eight interrelated compartments. The paper recommends that government should carefully scrutinize and thoroughly accredit all NGOs participating in the post-conflict areas, before granting license to operate. The paper concludes that the role of NGOs in the Post-conflict region should go/operate beyond humanitarian services, to include reconstruction and resettlement as lasting solution to the conflict.
\end{abstract}

Keywords: NGOs; Post-conflict; Peace-building; North-eastern Nigeria

\section{Introduction}

Nigeria as a Sovereign State in the African continent had been characterized or rather saddled with plethora of one conflict or the other before and after its birth in 1960. The conflict ranges from the political crises, ethno-religious conflicts, civil war and the contemporary indigene/settler dichotomy, threats of secession by some regions of the country (Nigeria) as well as the recent Boko Haram insurgent which ravaged almost the Northern Nigeria, and in particular the NorthEastern Nigeria with massacre of death told [1].

It is evident that the North-Eastern Nigeria is known for its peace and tranquility, hospitable and tourist attraction. Hence, the region has been greatly advanced in terms of economic activities where goods are nourished and feed other sections of Nigeria. Yankari Game Reserve in Bauchi, Dadin Kowa tomatoes and other perishable goods in Gombe, Beans production in Yobe State, dry fish and yam in Taraba, Yam and Rice also in Adamawa State. All these economic activities have been crippled due to insurgents of Boko Haram.

Educational development in the North-Eastern Nigeria is drastically affected. To the extent that the region ranked first in the Northern Nigeria, in the out of school children, according to Daily Trust, 2017 of 10 million out of school, in the Northern Nigeria, the North-East constitute seven million (7 million). What a pathetic?

The lack of political will in the part of the previous governments calls for exodus of non-governmental organization (NGOs) from various parts of the world.

\section{Operationalization of key concepts}

a. NGOs: This connotes Non-Governmental Organization such as the Civil Liberty Organizations, Red Cross etc. that saddled with the responsibilities of humanitarian services to internally displaced persons at mostly crisis prone areas.

From its initial conception as bulk-work against the church, Nongovernmental organizations has been the subject of intellectual debate.
Since the "third wave" began its course across the continent of Africa resulting in a plethora of scholarly views [2]. Interestingly attempt by pundits to clarify the concept have often been loaded with a tendency to juxtapose NGOs with the State and then probe the native and character of their relationship. For example, NGOs is seen as "society in its relation to the State.... In so far as it is in confirmation with the State, or more precisely as the process by which society seeks to break and counteract the simultaneous totalization unleashed by the State $[2,3]$.

Similarly, Earnest-Geller in his condition of liberty: Civil Society and its Rivals, defined NGOs as:

That set of diverse non-governmental institutions - which is strong enough to counter balance the State and while not preventing the State from fulfilling its role of keeper of peace and arbitrator between major interest, can nevertheless prevent it from dominating and atomizing the interest of society [4].

Beyond the corroborative views of Non-Governmental Society as a formidable opposition against the despotic tendency of the establishment, attempts have also been made by scholars to examine the nature and idiosyncrasies of civil society. in this direction, Azarya has identified three components. First, non-governmental society is a part of society comprising a set of autonomous institutions that are distinct from family, the class, the locality and the state. Secondly, it is

*Corresponding author: Ghani DM, School of General Studies, Abubakar Tatari Ali Polytechnic, Bauchi, Nigeria, Tel +234-8088525991; E-mail: abufatima25@yahoo.com

Received July 30, 2018; Accepted August 31, 2018; Published September 09, 2018

Citation: Mohammed GD, Yalwa A (2018) The Role of Non-Governmental Organizations (NGOs) in Post-Conflict Peace Building in North Eastern, Nigeria. Arts Social Sci J 9: 395. doi: 10.4172/2151-6200.1000395

Copyright: () 2018 Mohammed GD, et al. This is an open-access article distributed under the terms of the Creative Commons Attribution License, which permits unrestricted use, distribution, and reproduction in any medium, provided the original author and source are credited. 
a part of society that conducts a particular set of relationship between itself and the state possesses mechanisms that safeguard the separation of state and society and maintains effective ties between them. Thirdly, it is a widespread pattern of refined and civil manners which may also be called civility [2,5]. Although Azarya's conception of Nongovernmental organization offers great insight, the views of Diamond is alsohelpful in understanding contemporary meaning of NGOs. He posits that Non-governmental organization is:

The realm of organized social life that is voluntary, self generating, self supporting, autonomous from the state and bound by the legal order set of shared rules. It involves citizens acting collectively in a public sphere to express their interests, passions, and ideas, exchange ideas, exchange information, achieve mutual goals, made demands on the state, and hold state accountable. It is an intermediary entity, standing between the private sphere and the State [6].

In its broadest sense, the term "Non-governmental organization" refers to organization not based on government, not created to earn profit. The terminology of an NGO varies - they may be called "private voluntary organizations" and most African - NGOs prefer to be called "Voluntary Development Organizations"

World Bank conceptualized the NGOs as many groups and institutions that are entirely or largely independent of government and that have primarily humanitarian or cooperative rather than commercial objectives. They are private agencies in industrial countries that support international development; indigenous groups organized regionally or nationally; and member-groups in villages. NGOs include charitable and religious associations that mobilize private funds for development, distribute food and family planning services and promote community organization. They also include independent co-operatives, community associations, maker-user societies, and influence policy are also NGOs.

b. Post-conflict: This is a phenomena or which occurred after the conflict, even though there are pockets of conflict or insurgents in the area. Post conflict also identifies some activities in the conflict areas. However, there are emergence of new development in the area, such as the IDP camps, humanitarian bodies and other settlement activities. During post-conflict, there are series of government policies towards reconstruction of the area in question.

c. Peace building: This implies the process of low conflict and high prospects for development. On the other hand, peace building is a process that facilitates the establishment of durable peace and tries to prevent the reoccurrence of conflict by addressing the root causes and effect of conflict through reconciliation, institution building and politics as well as economic transformation.

d. North-Eastern Nigeria: This is a geographical location of some areas in a particular country (Nigeria). These regions include Bauchi, Gombe, Yobe, Maiduguri, Adamawa and Taraba. The area is part of the defunct regional arrangement and in the contemporary, six (6) geopolitical zone of Nigeria.

In the word of Chukwumah the four years of insurgency had brought loss of live and halted economic activities in the entire North-Eastern Nigeria [7]. The activities of Boko Haram have brought devastating effects on the region, suffering, destruction of infrastructures and public/private facilities. This situation has threatened not only the internal peace and security of the region but also the peace of Nigeria and beyond. So alarming is the fact that most of these areas affected by insurgency lack the will to stop this social charade and have fallen prey to continuous usury and subtle manipulation by politicians who take advantage of this situation to involve in shady deals like kidnapping and arms deals using insurgency as a cover [7]. Peace building has therefore become imperative, and most pressing challenge face by Nigeria at large and North-East in particular.

\section{Theoretical Framework (Elite Theory)}

Theories act as foundation of analysis especially if the analysis is social science oriented. Theoretical framework therefore, provides a focal guide within which to test our propositions, verify our variables. For this purpose, 'Elite theory' is adopted to guide the analysis and as well theoretical framework.

Scholastically, Elite theory had posited that power resides in and is always in the control of a network of elite. The proponents of Elite theory include Pareto Mosca, Robert Mitchels, C. Right Mills, Ortega Y and Gasset among others. They maintained that public policy is by and large the mirror image of elite interest. Further stressed that in order to understand public policy - one has to examine the socio-economic status as well as power relations within the community.

The underline premise of elite theory is that the masses are basically apathetic hence, elite are left to dominate the policy making process.

The major thrust or tenets of elite theory are summarized as follows:

a. Society is basically divided into few - who have power and allocate values for the society.

b. Elite are drawn mainly from the upper socio-economic strata of the society.

c. The movement of non elite to the elite class must be slow and continuous so as to maintain stability, and avoid revolution

d. Elite always try to defend the status quo-ante so as to protect and preserve their undue advantages over the masses.

e. Influence and power always flow from the elite and the top downwards to the masses.

f. The vast majority of people are destined to be ruled by the selected few [8].

It is evident, that in recent years the study of elite has come to occupy a prominent position on research agenda of political scientists, historians and other scholars in the social and behavioural fields [1] The elite theories originally developed in the classical literatures of the Greek by Gaetono Mosca Vilfedo and Robert Mitchel as mentioned earlier, has been progressively reassessed in the light of contemporary inquiries.

Based on the above analysis and the focus of the elite theory, the following are its strengths:

a. The elite theory prevents the involvement of large number of people in the decision-making that may end in time consuming and cumbersome.

b. It reduces the study of politics to power relations, infact if power proves to be inadequate principles for understanding politics, elite theory will collapse.

c. Elite tries to find a moral and legal basis for its being in the citadels of power and represent it as the logical and necessary consequences of doctrines and beliefs that are generally recognized and accepted. 
The strength of the elite theory in power relations, equally calls for its weaknesses which can be analyzed below:

The theory does not recognize the contribution of the masses in decision-making since they (the masses) are apathetic and unconscious in focus.

a. The theory does not condone a radical change, since the elite want to maintain the status quo-ante.

b. The elite theory also create a gap between the masses and those that occupied the political power, which invites conflicts.

c. The elite theory is eurocentric, since most of the proponents of the theory are non Africans.

In justifying the elite theory in post-conflict area, particularly in the North-Eastern Nigeria, where political elite, religious elite and organizational elite exist. But the political elite have politicized the insurgence as a conduit pipe for tapping resources from the conflict. This is in addition to lack of political will in the part of the government to end the conflict totally in the region.

Buttressing the politicization of insurgence activities in the NorthEastern Nigeria, ex-President Jonathan challenged Governor Shettima that "come clean on chibok girls" further stated that Shettima be clear on the role he played in the kidnapped of the chibok school girls. That Governor Shettima had ignoble roles in frustrating the war waged by the past administration against Boko Haram, even in his own Borno State [9].

In respond to Jonathan's challenged, Shettima asked Jonathan to explain why he hide Sabo Panel report? Maintained that Jonathan should explain why he deliberately concealed the report of a presidential fact finding committee he constituted and inaugurated in 2014 to probe the affair of Borno State Commission for Education.

Judging from the above elite conflict, when the game is over, it is clear to note that the role of elite conflict in conflict perpetration is when they have the same motive to achieve. Moreover, the same political elite that politicized the conflict resolution, for their self motives, were call upon in various committees of inquiry to investigate the causes of the conflict, and made recommendations for the lasting solution to the conflict. The theory has also justified the proposition of Ghani, Dass on the root causes of the indigene/settler conflict in Jos - North Local Government Area, Plateau State [1]. And rhyme with Robert Mitchel's view of "Iron law of Oligarchy" - that in every society there must be political elite.

However, in the North-eastern Nigeria, the masses are still apathetic hence due to their unconscious mind were manipulated by the political elite to execute the conflict.

\section{Role of NGOs in Post-Conflict Region}

Non-governmental organizations as body which complement the effort of the government in the conflict prone areas particularly in the North-Eastern region of Nigeria can be discussed as follows:

1. Provision of relief materials to the internally displaced persons, at the various camps of the region. Infact colossal sum of money was earmarked by NGOs to alleviate the sufferings of the internally displaced persons.

2. Establishment of schools for the internally displaced persons. Since there are millions of out of school children in the region. Statistics has shown that the insurgents in the region have rendered about 7 million children out of school.
3. NGOs have engaged in counterpart funding with the Federal and the State of the region, in financing some basic needs of the internally displaced persons.

4. Provision of health care services to the victims of the conflict.

5. Advocacy/awareness campaign on the implication of the youths involvement in insurgents and the need to be educated through entrepreneurial skills and vocation.

6. Re-settlements of the internally displaced persons at various camps for proper care [9].

\section{Challenges}

The role of NGOS in the post-conflict region, equally call for its challenges as well as the weakness inherent with the body in the said areas as follows:

1. Diversion of the relief materials by some unpatriotic officials who were entrusted with the public resources.

2. There were emergence of fake NGOs operating in the region, without being properly accredited. This in itself, has accorded a bad image on the role of NGOs in the post-conflict areas.

3. Some NGOs hide under the guide of humanitarian services, to gain more profit since resources is allocated to the project or mission. This also hampered the activities of the NGOs in the region.

4. There are challenges from different quarters, that most of the activities of NGOs concentrated in the urban cities of the region, while the rural areas were given least attention.

5. The prevalent and rampant cases of raping have become a serious challenge on the activities of NGOs in the postconflict areas.

6. There are contradictory reportage on the part of the NGOs, on the security network at various IDPs camp. This resulted to soar and media conflict, between the NGOs and the military contingents at the region [10-13].

\section{Conclusion}

This paper has attempted to examine the role of non-governmental organizations (NGOs) in post-conflict peace building in North-eastern Nigeria. The paper therefore concludes that the role of NGOs in the post-conflict region should go beyond humanitarian services to include - reconstruction and re-settlement of victims of the conflicts as lasting solution to the conflict [14-16]. The paper also recommends that NGOs should be thoroughly accredited to fish out the rotten and fake emerging NGOs in the activism. This is addition to objective reportage on the security, issue of the region.

\section{References}

1. Dass MG (2015) The Crisis of Citizenship in Nigeria: A study of Indigene/Settler Conflict. Jos North Local Government Area Plateau State, Unpublished MSc Thesis at the Department of Political Science ABU Zaria.

2. Abdulhamid O (2007) Civil Society and Democratic Consolidation in Nigeria challenged and prospects. Nigerian Journal of Political Science ABU Zaria.

3. Bayart JF (1986) Civil Society in Africa in Patrick Chabal (ed) Political Domination. Africa Oxford University Press.

4. Geller E (1995) Condition of Liberty: Civil Society and its Rival.

5. Azarya V (1994) Civil Society and Disengagement in Africa. Harberson JW (ed.) Civil Society and State in Nigeria Bowder. 
Citation: Mohammed GD, Yalwa A (2018) The Role of Non-Governmental Organizations (NGOs) in Post-Conflict Peace Building in North Eastern, Nigeria. Arts Social Sci J 9: 395. doi: 10.4172/2151-6200.1000395

Page 4 of 4

6. Diamond L (1999) Developing Democracy towards Consolidation Baltimore: John Hopkins University.

7. Chukwumah I (2005) Government - Civil Society Partnership in Nigeria: Problem and Prospects Paper presented at the Special Retreat on Government Civil Society Partnership organized by the National Orientation Agency in collaboration with Office of the Special Adviser to the President on Civil Society at the Multipurpose Arts Theatre Gamji Gate Kaduna pp:12-15.

8. Dlakwa H (2003) Reading Monograph in Public Policy Analysis using the Elite Theory. Department of Political Science and Administration University of Maiduguri - Nigeria.

9. Daily Trust (2017) Northern Nigeria Constitute the highest out of School children Vol-6.

10. Samuel U (2003) Movement for Youth Actualization International (MYAI) a Non-Governmental Organization (NGOs) in Nigeria.
11. Eldis (2003) Aid NGOs and Civil Society.

12. Heater DB (1994) Political Ideas in Modern World George G Harrap and Co Ltd.

13. Kukah MH (2003) Democracy and Civil Society in Nigeria Spectrum Books Limited Ibadan.

14. NNO Funding and Policy (2001): Interact NGO Research Programme.

15. Pareto V (1938) The Mind and Society - Harcourt - Brace New York in Geraint Party Political Elite University of Manchester London George Allen and Unwin Ltd Reuskin House Museum Street.

16. Role of Non-Governmental Organizations in Development Cooperation (1993) 